\title{
Intergenic Spacer-RFLP Analysis and Direct Quantification of Australian Fusarium oxysporum f. sp. vasinfectum Isolates from Soil and Infected Cotton Tissues
}

\author{
A. G. Zambounis, Department of Genetics and Plant Breeding, Aristotle University of Thessaloniki, GR-540 06 \\ Thessaloniki, Greece; E. Paplomatas, Department of Plant Pathology, Agricultural University of Athens, 75 Iera \\ Odos, GR-118 55 Athens, Greece; and A. S. Tsaftaris, Department of Genetics and Plant Breeding, Aristotle Univer- \\ sity of Thessaloniki, GR-540 06 Thessaloniki, Greece, and Institute of Agrobiotechnology (IN.A.) - Center for Re- \\ search and Technology Hellas (CERTH), GR-570 01 Thermi, Thessaloniki, Greece
}

\begin{abstract}
Zambounis, A. G., Paplomatas, E., and Tsaftaris, A. S. 2007. Intergenic spacer-RFLP analysis and direct quantification of Australian Fusarium oxysporum f. sp. vasinfectum isolates from soil and infected cotton tissues. Plant Dis. 91:1564-1573.

Fusarium wilt of cotton, caused by Fusarium oxysporum f. sp. vasinfectum, can have devastating effects on the vascular system of cotton plants and is a major threat to cotton production throughout the world. Accurate characterization and improved detection of these pathogenic isolates is needed for the implementation of a disease prevention program and the development of disease management strategies. Polymerase chain reaction (PCR) amplification of the ribosomal intergenic spacer (IGS) regions combined with digestion with three restriction enzymes (AluI, HaeIII, RsaI) resulted in three unique restriction profiles (IGS-restriction fragment length polymorphism [RFLP] haplotypes) for Australian $F$. oxysporum f. sp. vasinfectum isolates, which were capable of distinguishing them from other formae speciales of $F$. oxysporum. Furthermore, a portion of the IGS region flanking the $5^{\prime}$ end was sequenced and single nucleotide polymorphisms (SNPs) were revealed. Using these sequence data, two specific real-time PCRbased assays were developed for the absolute quantification of genomic DNA from isolates obtained from soil substrates and infected cotton tissues. Standard curves of real-time PCR-based assays showed a linear relation $\left(R^{2}=0.993\right.$ to 0.994$)$ between log values of fungal genomic DNA and real-time PCR cycle thresholds. Using these assays, it was possible to detect fungal DNA as low as $5 \mathrm{pg} / \mu \mathrm{l}$. The detection sensitivity for inoculum added to sterile soils was lower than $10^{4}$ conidia/g soil. In plant samples, the quantified fungal DNA varied from $30 \mathrm{pg}$ to $1 \mathrm{ng} / 100 \mathrm{ng}$ of total plant genomic DNA.
\end{abstract}

Additional keywords: Gossypium hirsutum, molecular detection

Fusarium oxysporum (5) is well known to cause vascular diseases on a broad range of agricultural and ornamental plant species. In order to characterize and study the wide diversity of $F$. oxysporum isolates infecting a variety of plant hosts, Snyder and Hansen (40) have proposed a classification system that arranges individual pathogenic strains with similar or identical host range into groups called formae speciales. In this manner, Fusarium wilt of cotton is caused by $F$. oxysporum f. sp. vasinfectum and has been reported as a major threat to cotton production (16). Several races have been characterized

Corresponding author: A. S. Tsaftaris

E-mail: tsaft@certh.gr

Accession numbers: AY997771 through AY997790 (www.ncbi.nlm.nih.gov).

* The $\boldsymbol{e}$-Xtra logo stands for "electronic extra" and indicates that Figures 3 through 6 appear in color in the online edition.

Accepted for publication 27 June 2007.

doi:10.1094/PDIS-91-12-1564

(c) 2007 The American Phytopathological Society within this forma specialis, such as American races 1, 2, and 6, Egyptian race 3, and Indian race 4 (15). In Australia, Fusarium wilt of cotton was first confirmed in 1993, and since then it has spread significantly in the country. It has been reported that the disease is attributable to two pathogenic biotypes, 01111 and 01112 vegetative compatibility groups (VCGs) that are vegetatively incompatible (16). Later, genetic analyses indicated that the isolates were clearly distinct from the American isolates and formed an independent clade (26). Furthermore, Kim et al. (26) reported the occurrence of $F$. oxysporum f. sp. vasinfectum races 3, 4, and 8 in California as possible causes of serious economic losses in some cotton fields due to the importation of large quantities of infected Australian cotton seed to California. Davis et al. (15) assumed that Australian biotypes were limited to Australia. In a 1952 survey, isolates of $F$. oxysporum f. sp. vasinfectum were not detected in Greece (2) and currently remain unreported in this country.

Nuclear ribosomal DNA (rDNA) is known to be a useful source of inter- and intra-specific polymorphisms in fungal species (23). Ribosomal genes exist in multiple copies that are arranged in tandem repeats interrupted by noncoding spacer regions. The intergenic spacer (IGS) region is located between the large and small subunit of consecutive cistrons and is reported to be evolving more rapidly than any other region in rDNA repeat units. IGS polymorphisms, based on length or sequence variation, can distinguish between closely related species. Numerous studies have reported the application of an approach involving restriction digestion of polymerase chain reaction (PCR) products to identify polymorphisms in IGS or internal transcribed spacer regions (ITS1 and ITS2) for conducting diversity studies between Fusarium species or individual isolates within a Fusarium species $(3,12,26,27)$.

Real-time PCR technology can accurately quantify the extent of pathogen biomass and, with multiplex formats, can simultaneously detect different organisms. The applications of this technique are based on the use of fluorogenic probes (hybridization probes or exonuclease probes such as TaqMan) (32) or dyes (SYBR Green dye) (31). In contrast to fluorogenic probes, the SYBR Green dye does not require the design of specific fragments complementary to the target DNA. Because the dye has no sequence specificity, it can be used to detect any double-stranded (ds) DNA PCR product. In its unbound state, SYBR Green emits relatively low fluorescence, but it fluoresces brightly when bound to dsDNA. As the amount of amplification product increases, the amount of fluorescence emitted by the dye increases proportionally (6).

This technology is being used increasingly in plant pathology for the accurate detection and quantification of plant pathogens, even at very low levels of infection $(7,9,18,36-38,41-43,45)$. However, its application for the detection and quantification of fungi from soil samples remains difficult for Helminthosporium solani (14), Colletotrichum coccodes (13), Rhizoctonia solani (28), F. solani f. sp. glycines (29), and $F$. oxysporum f. sp. niveum (46).

In order to prevent and monitor the possible spread of the Australian F. oxysporum f. sp. vasinfectum isolates in Greece and other cotton growing areas, a reliable and rapid characterization and diagnostic method is needed that allows for the detec- 
tion of contaminated plant or soil samples. Therefore, the objectives of this research were to develop: (i) unique IGS-restriction fragment length polymorphism [RFLP] markers that can be used to characterize and differentiate Australian F. oxysporum f. sp. vasinfectum (VCG01111 and VCG01112) isolates from other cotton root fungal colonizers and especially from other formae speciales of $F$. oxysporum and (ii) reliable real-time PCR assays for the quantification of these isolates from various tissues of cotton cultivars and representative soil types.

\section{MATERIALS AND METHODS}

Fungal isolates and growth conditions. Six isolates of $F$. oxysporum $\mathrm{f}$. sp. vasinfectum (FOV) (three of each VCG) from Australia, seven isolates of $F$. oxysporum formae speciales, four nonpathogenic $F$. oxysporum isolates, two isolates of other Fusarium species, and two fungal isolates of Verticillium dahliae and Thielaviopsis basicola that cause cotton vascular wilt disease and black root rot, respectively, were included in this study (Table 1). Cultures of all isolates were maintained on potato dextrose agar (PDA) at $4^{\circ} \mathrm{C}$. For DNA extraction, cultures were grown in $250 \mathrm{ml}$ of potato dextrose broth (PDB) in a rotary shaker at $180 \mathrm{rpm}$ for 4 days at $28^{\circ} \mathrm{C}$. After vacuum filtration, the mycelia were lyophilized, ground with sand using a mortar and pestle, and stored at $-20^{\circ} \mathrm{C}$.

Conidia of pure $F O V$ cultures (isolates FOV 1.2 and FOV 2.1) selected for construction of real-time PCR-based standard curves and inoculations of plant samples were produced on potato-carrot medium (13). Cultures were incubated at $22^{\circ} \mathrm{C}$ under a fluorescent and a black light $(16 \mathrm{~h}$ day/8 h night) for 10 days. To obtain a conidial suspension, the surface of each culture plate was flooded with $2 \mathrm{ml}$ of sterile distilled water, agitated for $30 \mathrm{~s}$ by manually swirling each petri plate, serially diluted, and adjusted using a hemacytometer to the desired concentrations of $5 \times 10^{7}$, $5 \times 10^{6}, 5 \times 10^{5}, 5 \times 10^{4}$, and $5 \times 10^{3}$ conidia/ml (pure FOV cultures). For plant inoculations, a dilution of $10^{7}$ conidia $/ \mathrm{ml}$ was used for drenching young (5 week old) cotton plantlets of cvs. Lacta and Emerald maintained in a growth chamber under optimal conditions $\left(28^{\circ} \mathrm{C}\right.$ day $/ 26^{\circ} \mathrm{C}$ night with a $16-\mathrm{h}$ photoperiod at $65 \%$ relative humidity).

Soil preparation and inoculation. Soil samples were collected from two cotton cultivation sites in Greece representing two different soil types. The sites were located at Larissa lowlands (the main area of cotton cultivation in Greece), soil type sandy loam (type A), and at Thessaloniki University Farm in Northern Greece, soil type clay loam (type B). Soil mixtures consisting of one part of the two above sieved (3 $\mathrm{mm}$ ) field soils were thoroughly mixed with one part each of Turface (Profile
Products LLC, IL), peat (4-mm sieved), and perlite as described by Fillion et al. (22). The soil mixtures were autoclaved for $30 \mathrm{~min}$ at $121^{\circ} \mathrm{C}$ three times on three consecutive days before use (sterile soil substrates). Soil filtrates prepared from suspensions of $20 \mathrm{~g}$ of field soil diluted in 1 liter of distilled water were added to the sterile soil substrates in order to reintroduce soil microflora. These preparations were used only as negative controls for testing the specificity of primer pairs to detect only the Australian FOV isolates in soil samples.

Samples consisting of $2 \mathrm{ml}$ each of $F O V$ 1.2 and FOV 2.1 conidia suspensions $\left(10^{7}\right.$, $10^{6}, 10^{5}, 10^{4}$, and $10^{3}$ conidia/ml) were added to $2 \mathrm{~g}$ of sterile soil substrates. Controls consisted of duplicate tubes containing sterile or nonsterile soil substrates inoculated with $2 \mathrm{ml}$ of sterile distilled water. All tubes were vortexed for $1 \mathrm{~min}$, freeze-dried for 2 to 3 days, and stored at $-80^{\circ} \mathrm{C}$ prior to soil fungal genomic DNA extraction.

DNA extraction. Genomic fungal and plant DNA was extracted according to DNeasy Plant Mini Kit (Qiagen Inc., Chatsworth, CA). Total soil genomic DNA was isolated with the UltraClean Soil DNA Kit from MoBio Laboratories, Inc. (Solana Beach, CA) according to the manufacturer's protocol without any modification and stored at $-20^{\circ} \mathrm{C}$. DNA concentrations were determined spectrophotometrically and/or by quantitation on agarose gels stained with ethidium bromide in comparison with molecular marker $\lambda$-DNA-HindIII (Gibco-BRL, Gaithersburg, MD).

PCR amplification of the IGS regions. The IGS regions of all fungal strains used in this study were amplified by the univer- sal primers CNL12 and CNS1 (44). Amplifications were performed in $50-\mu$ l reaction mixtures containing $5 \mu \mathrm{l}$ of $10 \times$ PCR buffer; $0.2 \mu \mathrm{M} \mathrm{Mg}{ }^{2+}, 0.2 \mu \mathrm{M}$ of each primer, $0.2 \mathrm{mM}$ each deoxyribonucleotide triphosphate (dNTPs), 0.5 units of DyNAzyme II DNA polymerase (Finnzymes, Espoo, Finland), and $100 \mathrm{ng}$ fungal DNA A PTC-200 thermocycler (MJ Research, Waltham, MA) was used with an initial denaturation step of $5 \mathrm{~min}$ at $94^{\circ} \mathrm{C}$ followed by 35 cycles of $1 \mathrm{~min}$ at $94^{\circ} \mathrm{C}, 1$ $\min$ at $55^{\circ} \mathrm{C}, 2 \min$ at $72^{\circ} \mathrm{C}$, and a final step of $10 \mathrm{~min}$ at $72^{\circ} \mathrm{C}$. Amplification products were separated by electrophoresis through $1.5 \%$ (wt/vol) agarose gels in $1 \times$ TBE buffer. Gels were stained with ethidium bromide and photographed on a UV transilluminator.

Restriction digestion of PCR products and phylogenetic analysis of the IGSRFLP haplotypes. Amplified PCR products were purified by precipitation by adding 0.1 volume of $3 \mathrm{M}$ sodium acetate and 2.5 volumes of absolute ethanol to remove excess dNTPs and primers, and then resuspended in sterile distilled water. Four restriction enzymes $(10 \mathrm{U} / \mu \mathrm{l})$ were used to digest amplified DNA: AluI, RsaI, HaeIII, TaqI $a$ (New England Biolabs, Beverly, MA) according to the manufacturer's instructions. Electrophoresis of the restriction fragments was carried out in $1.5 \%$ agarose or $3.5 \%(\mathrm{wt} / \mathrm{vol})$ metaphor gel (FMC Bioproducts, Rockland, ME) in $1 \times$ TBE buffer. The molecular size of each fragment was estimated precisely using the original UVIDoc Mw package (St John's Innovation Center, Cambridge, UK) software by comparisons with standard DNA molecular weight markers (Cambrex, Rockland, ME).

Table 1. Fungal species used in this study with their abbreviations, number of isolates, and host/geographic origin

\begin{tabular}{|c|c|c|c|}
\hline Fungal species & $\begin{array}{l}\text { Isolate } \\
\text { abbreviation }\end{array}$ & $\begin{array}{l}\text { No. of } \\
\text { isolates }\end{array}$ & Host/collection site \\
\hline $\begin{array}{l}\text { Fusarium oxysporum f. sp. vasinfectum } \\
\text { (VGG 01111) }\end{array}$ & $\begin{array}{l}\text { FOV 1.1, FOV 1.2, } \\
\text { FOV 1.3 }\end{array}$ & 3 & Cotton/Australia ${ }^{y}$ \\
\hline $\begin{array}{l}\text { F. oxysporum f. sp. vasinfectum } \\
(\text { VGG 01112) }\end{array}$ & $\begin{array}{l}\text { FOV 2.1, FOV 2.2, } \\
\text { FOV } 2.3\end{array}$ & 3 & Cotton/Australia ${ }^{y}$ \\
\hline F. oxysporum f. sp. phaseoli (F123) & FOP & 1 & Phaseolum/Kastoria ${ }^{\mathrm{z}}$ \\
\hline F. oxysporum f. sp. lycopersici (F421) & FOL & 1 & Tomato/Kiparissia ${ }^{\mathrm{z}}$ \\
\hline $\begin{array}{l}\text { F. oxysporum f. sp. radicis.cucumericum } \\
\text { (F614) }\end{array}$ & FORC & 1 & Cucumber/Triffilia $^{z}$ \\
\hline $\begin{array}{l}\text { F. oxysporum f. sp. radicis.lycopersici } \\
(\text { F623) }\end{array}$ & FORL & 1 & Cucumber/Ierapetra $^{\mathrm{z}}$ \\
\hline F. oxysporum f. sp. niveum (F42) & FON & 1 & Watermelon/Agrinio ${ }^{z}$ \\
\hline F. oxysporum f. sp. melonis (F589) & FOM & 1 & Melon/Alexandroupoli ${ }^{\mathrm{z}}$ \\
\hline F. oxysporum f. sp. dianthi (F636) & $F O D$ & 1 & Carnation/Marathonas ${ }^{\mathrm{z}}$ \\
\hline F. oxysporum $(F 389)$ & FOX & 1 & Tomato/Ag. Vlassis ${ }^{\mathrm{Z}}$ \\
\hline F. oxysporum (F371) & FONP 1 & 1 & Tomato/Ag. Vlassis ${ }^{\mathrm{z}}$ \\
\hline F. oxysporum (F388) & FONP 2 & 1 & Tomato/Ag. Vlassis ${ }^{\mathrm{Z}}$ \\
\hline F. oxysporum (F376) & FONP 3 & 1 & Tomato/Ag. Vlassis ${ }^{\mathrm{Z}}$ \\
\hline$F$. proliferatum $(F 647)$ & FPRO 1 & 1 & Asparagus/Kavala ${ }^{z}$ \\
\hline F. proliferatum (F643) & FPRO 2 & 1 & Asparagus/Orestiada ${ }^{\mathrm{z}}$ \\
\hline Thielaviopsis basicola (BPIC1693) & TBAS & 1 & Tobacco/Locrida $^{\mathrm{z}}$ \\
\hline Verticillium dahliae (70V) & VERT & 1 & Tomato/Scala ${ }^{z}$ \\
\hline
\end{tabular}

${ }^{y}$ Isolates were obtained from W. O'Neill (Plant Pathology Building, Department of Primary Industries, Indooroopilly, Queensland, Australia).

${ }^{\mathrm{z}}$ Isolates were obtained from K. Elena (Benaki Phytopathological Institute of NAGREF, Athens, Greece). 
The phylogenetic analysis based on the RFLP patterns was performed using the RESTDIST procedure of PHYLIP version 3.62 software (19). Subsequently, a neighbor-joining tree (NJ) with 1,000 bootstrap replicates was reconstructed from the distance matrix using Neighbor program (20), and the trees were exported into TreeView version 1.6.6 as described by Page (33). Isolate FOV 1.1 was included as an outgroup sample.

Sequencing of IGS fragments and design of $\mathrm{FOV}$-specific primers. PCR amplification products of all fungal IGS regions were purified using the NucleoSpin Extract Kit (Macherey Nagel, Duren, Germany) in order to remove secondary metabolites prior to sequencing. The $5^{\prime}$ end of each fragment was sequenced using the reverse primer CNS1. Sequencing was carried out by the DNA facility in the Laboratory of Institute of Molecular Biology and Biotechnology (I.M.B.B., Crete, Greece) in a Long Read IR2 4200 DNA sequencer (Li-Cor, Lincoln, NE). Gene sequence data are available in the GenBank database under accession numbers AY997771 through AY997789 and AY997790.

Two sets of Australian $F O V$-specific primer pairs, FOV-1/FOV-2 and FOV3/FOV-4, were commercially synthesized based on the previously described IGS sequence. The FOV-1 (5'-TGTAGG GGTTGTGGGTTTTTTTC-3') and FOV-2 (5'-CCAACACACAACCGCACACGA-3') primers, which flank a 125 -bp DNA fragment located near the $5^{\prime}$ end of the IGS rRNA gene, were used to amplify all three isolates of VCG01111 and one isolate (FOV 2.3) of VCG01112. The FOV-3 (5'AGCAGTAGAGTAGCCTTGTTG- ${ }^{\prime}$ ) and FOV-4 (5'-TTCCACCAAGTCTAACTC GC-3') primers were designed to generate a 165-bp DNA product from the $5^{\prime}$ end of isolates FOV 2.1 and FOV 2.2 (VCG01112). The specificity of each primer pair was confirmed by absence of significant homology with other known DNA sequences using the Basic Local Alignment Search Tool (BLAST) of the GenBank database. To evaluate the specificity of these Australian $F O V$-specific primer pairs, we extended our work to two other isolates of FOV races: race 3 (Egyptian) and race 4 (Indian) obtained from $C$. Steinberg (INRA, Dijon, France).

Standard curves and real-time PCR amplification. Standard fluorescent ampli- fication curves representing an exponential growth of PCR products based on cycle thresholds $\left(\mathrm{C}_{\mathrm{T}}\right)$ for 10 -fold dilution series of pure fungal cultures genomic DNA $(5 \times$ $10^{1}, 5 \times 10^{0}, 5 \times 10^{-1}, 5 \times 10^{-2}$, and $5 \times 10^{-3}$ $\mathrm{ng} / \mu \mathrm{l})$ were constructed for the two representative Australian $F O V$ isolates (FOV 1.2 and FOV 2.1) detected by the corresponding specific primer pairs. $C_{T}$ values were calculated to indicate significant fluorescence signals rising above background during the early cycles of the exponent amplification phase of the real-time PCR process.

Quantitative PCR amplifications were carried out in a total volume of $25 \mu$ using an Opticon 2 (MJ Research) real-time PCR system. PCR was performed in $1 \times$ PCR buffer, $0.2 \mathrm{mM}$ dNTPs, $0.4 \mathrm{pmol}$ for each FOV primer, 0.2× SYBR Green (SigmaAldrich, Dorset, UK), and $1 \mathrm{U}$ of the DyNAzyme II DNA polymerase (Finnzymes). Different concentrations of FOV conidia were added to sterile soil. DNA was extracted from these amended soil samples, and $4 \mu \mathrm{l}$ of the undiluted DNA extract was amplified as described above to examine the relationship between the number of conidia in a soil sample and real-time PCR results. In separate reactions, $4 \mu \mathrm{l}(100 \mathrm{ng})$ of DNA extracted from plant tissues were used for real-time PCR. Template control reactions contained $4 \mu \mathrm{l}$ of sterile water replacing the DNA solution. The thermal cycling conditions for FOV 1.2 isolate (VCG01111) and FOV 2.1 isolate (VCG01112) DNA template amplification were: incubation at $94^{\circ} \mathrm{C}$ for 5 min, followed by 35 cycles of $1 \mathrm{~min}$ at $94^{\circ} \mathrm{C}, 30 \mathrm{~s}$ at $61^{\circ} \mathrm{C}$ and $63^{\circ} \mathrm{C}$, respectively, and $1 \mathrm{~min}$ at $72^{\circ} \mathrm{C}$, and a final extension step of $5 \mathrm{~min}$ at $72^{\circ} \mathrm{C}$. For identification of the PCR products, a melting curve was performed from 65 to $95^{\circ} \mathrm{C}$ by reading every $0.2^{\circ} \mathrm{C}$ with a 10 -s hold between each temperature increment. All reactions were performed in triplicate.

Post-PCR statistical analysis. Statistical analyses were performed using the Correlation and General Linear Model procedure of the SPSS (version.12) statistical software (SPSS Institute, 1998). The relation between CT and fungal DNA concentration was analyzed by correlation analyses. The effect of conidia concentration on fungal genomic DNA quantification was analyzed by multifunctional ANOVA (three-way ANOVA) in which we examined the main level effect of each factor, as well as two-way and three-way interactions be- tween factors. For each factor, we made all possible by two comparisons (Post hoc tests) between all levels using the Sidak correction test (24). Significant differences were detected at $P<0.05$.

\section{RESULTS}

IGS-RFLP analysis. A PCR procedure using the universal primers CNL12 and CNS1 was conducted to amplify the IGS region of all isolates, and a single fragment was generated from each isolate (Fig. 1). The average size of the amplified fragments was approximately $2.6 \mathrm{~kb}$. A considerable decrease in length of amplified fragments was revealed with $F O P$ and VERT isolates (Fig. 1). The observed polymorphism for sizes of fungal IGS regions of even similar formae speciales is well documented (20). In our experiments, the lengths of the IGS regions were also estimated by a summation of individual fragment sizes generated by RFLP analysis. However, this estimation was different for each enzyme used and did not always match the sizes of the nondigested regions even when Metaphor high-resolution agarose was used (Fig. 2).

Digestion of the IGS regions with the four restriction enzymes generated 53 (16 AluI-IGS, 13 TaqIa-IGS, 12 RsaI-IGS, and 12 HaeIII-IGS) different restriction patterns (Table 2). Three AluI restriction profiles were identified that were unique to Australian FOV isolates (Table 2). A single $R s a \mathrm{I}$ and two HaeIII restriction profiles were identified that were unique to Australian FOV isolates. No restriction profiles unique to $F O V$ isolates were identified from digestions of IGS regions with TaqI $a$. In total, 18 IGS haplotypes were identified based on restriction analysis, of which three were haplotypes unique to $F O V$ isolates (Table 2).

Phylogenetic analysis of the data generated a consensus tree in which several robust clusters could be observed (Fig. 3). The Australian isolates formed clusters that appear to be independent of each other. Specifically, two isolates of VCG01112 (FOV 2.1/FOV 2.2), two isolates of VCG01111 (FOV 1.2/FOV 1.3), two isolates of FPRO, and FONP 1 and FONP 3 form distinct clusters supported by bootstrap values higher than $90 \%$. The other two remaining $F O V$ isolates were not grouped in the same clusters and showed little genetic similarity to their corresponding VCGs. All isolates were classified into

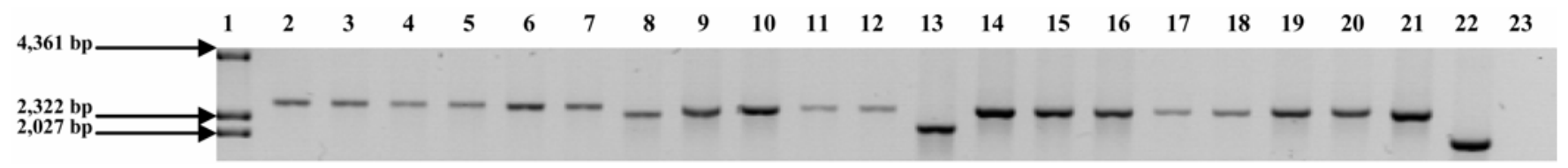

Fig. 1. Polymerase chain reaction (PCR) amplification products corresponding to the intergenic spacer (IGS) regions of the 21 fungal isolates used in the present study using primers CNL12/CNS1 visualized on EtBr-stained agarose gel (1.5\%). Lanes: 1, molecular marker $\lambda$-DNA-HindIII/ $\varphi$ X-HaeIII; 2-4, three different isolates of FOV VCG01111; 5-7, three different isolates of FOV VCG01112; 8, FOP; 9, FOL; 10, FORC; 11, FORL; 12, FON; 13, FOM; 14, FOX; 15, FOD; 16, FONP 1; 17, FONP 2; 18, FONP 3; 19, FPRO 1; 20, FPRO 2; 21, TBAS; 22, VERT; 23, $\mathrm{H}_{2} \mathrm{O}$. 
five major lineages based on this analysis, where FOV isolates were observed in the separate lineages I, V, and II (Table 3).

Sequence data, design, and specificity of $\boldsymbol{F O V}$-specific primers. IGS amplicons also were used as templates for direct sequencing of a portion of the IGS region flanking the $5^{\prime}$ end. A fragment ranging in size from 442 to $451 \mathrm{bp}$ was obtained for all isolates with the exception of FOM, for which a fragment of 378 bp was identified. A unique sequence was identified for each isolate except for FORL and FORC, for which identical sequences were determined. Single nucleotide polymorphisms (SNPs) unique for isolates of FOV were identified by nucleotide alignments of the sequenced portions of IGS regions of all fungal isolates used (data not shown). Two sets of $F O V$-specific primer pairs (FOV1/FOV-2 and FOV-3/FOV-4) were subsequently designed in order to exploit SNPs in the $3^{\prime}$ region that differentiate Australian $F O V$ isolates from other isolates. Comparisons of each primer sequence with nucleotide sequences of other plant-pathogenic fungi and bacteria deposited in GenBank databases revealed no significant levels of similarity. The specificity of these primers for $F O V$ isolates was tested, and a specific product $(125 \mathrm{bp})$ was reliably detected after conventional or real-time PCR using primers FOV-1/FOV-2. Similarly, primer pairs FOV-3/FOV-4 amplified a unique DNA fragment of approximately $165 \mathrm{bp}$ (Fig. 4A and B).

However, fragments of the same size as those generated from $F O V$ isolates were also unexpectedly amplified from an iso-

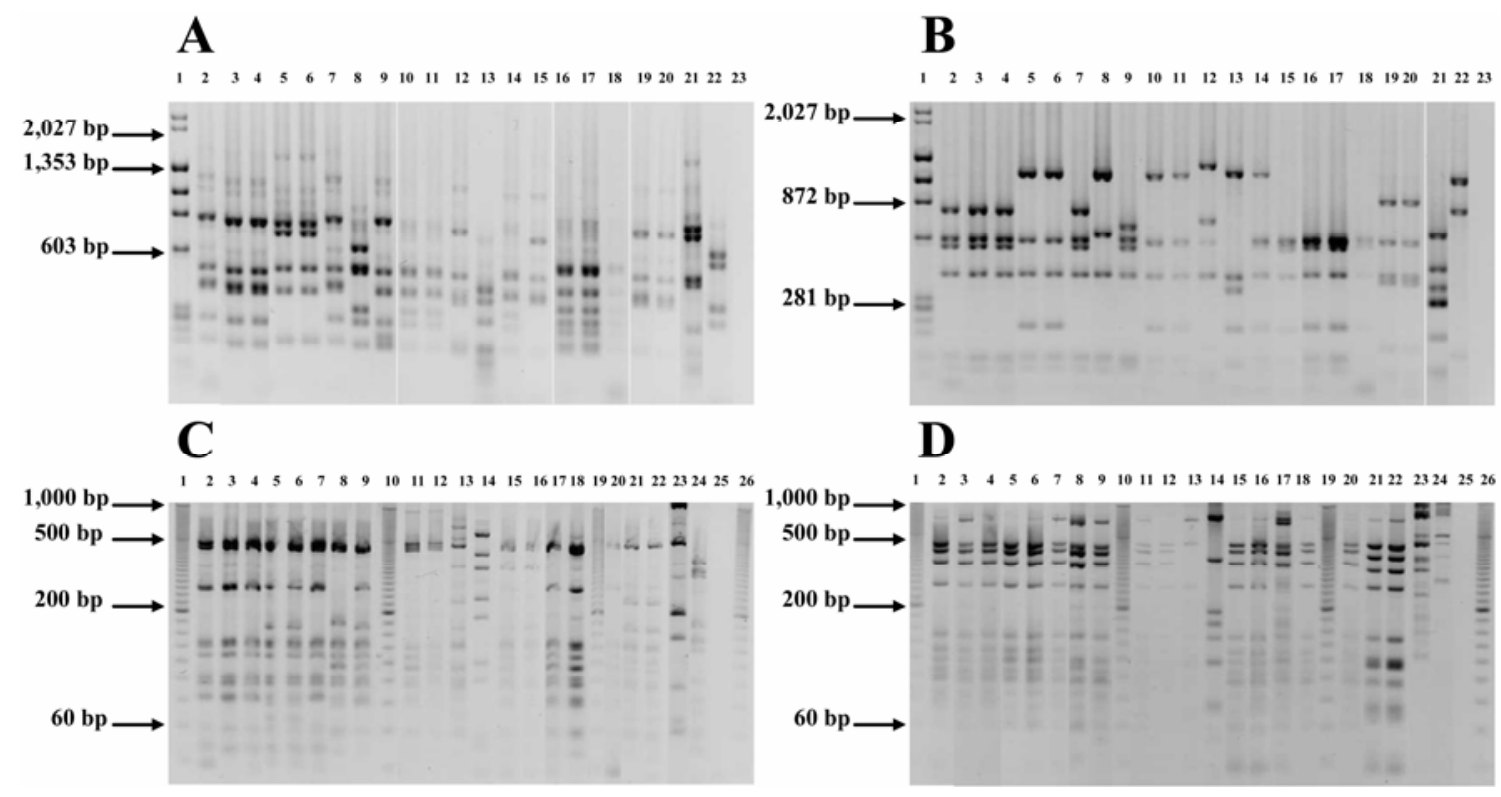

Fig. 2. Restriction fragments generated by restriction fragment length polymorphism (RFLP) analysis on polymerase chain reaction (PCR)-amplified intergenic spacer (IGS) regions of the 21 fungal isolates used in the present study visualized on EtBr-stained agarose (1.5\%, A and B) or metaphor (3.5\%, C and D) gel after digestion with the restriction endonucleases $A l u \mathrm{I}(\mathbf{A}), \operatorname{Rsa\mathrm {I}}(\mathbf{B}), \operatorname{Ha} e \mathrm{III}(\mathbf{C}), \operatorname{TaqI} a(\mathbf{D})$. A and B, Lanes: 1, molecular markers $\lambda$-DNAHindIII/ $\varphi$ X-HaeIII; 2,6,7, three different isolates of FOV VCG01111; 3-5, three different isolates of FOV VCG01112; 8, FOP; 9, FOL; 10, FORC; 11, FORL; 12, FON; 13, FOM; 14, FOX; 15, FOD; 16, FONP 1; 17, FONP 2; 18, FONP 3; 19, FPRO 1; 20, FPRO 2; 21, TBAS; 22, VERT; 23, H $2 \mathrm{O}$. C and D, Lanes: 1,10,19,26, molecular markers 20 bp ext. ladder; 2,6,7, three different isolates of $F O V$ VCG01111; 3-5, three different isolates of $F O V$ VCG01112; 8, FOP; 9, FOL; 11, FORC; 12, FORL; 13, FON; 14, FOM; 15, FOX; 16, FOD; 17, FONP 1; 18, FONP 2; 20, FONP 3; 21, FPRO 1; 22, F PRO 2; 23, TBAS; 24, VERT; $25, \mathrm{H}_{2} \mathrm{O}$.

Table 2. Distribution of lineage groups and intergenic spacer (IGS) haplotypes based on IGS-restriction fragment length polymorphism (RFLP) patterns of the 21 fungal isolates used in the present study

\begin{tabular}{|c|c|c|c|c|c|c|}
\hline \multirow[b]{2}{*}{ Isolates } & \multirow[b]{2}{*}{ Lineage } & \multirow[b]{2}{*}{ IGS haplotypes } & \multicolumn{4}{|c|}{ IGS-RFLP pattern } \\
\hline & & & Alu $\mathrm{I}$ & RsaI & HaeIII & $\operatorname{Taq} \mathbf{I} a$ \\
\hline $\begin{array}{l}\text { Fusarium oxysporum f. sp. vasinfectum } \\
\text { FOV } 1.1 \text { (VGG01111) / FOV } 2.3 \text { (VGG01112) }\end{array}$ & I & 1 & A & A & A & A \\
\hline $\begin{array}{l}\text { F. oxysporum f. sp. vasinfectum } \\
\text { FOV } 1.2(\mathrm{VGG} 1111) / \text { FOV } 1.3(\mathrm{VGG} 01111)\end{array}$ & V & 2 & B & A & A & A \\
\hline $\begin{array}{l}\text { F. oxysporum f. sp. vasinfectum } \\
\text { FOV } 2.1 \text { (VGG01112)/ FOV } 2.2(\mathrm{VGG} 01112)\end{array}$ & II & 3 & $\mathrm{C}$ & B & B & A \\
\hline F. oxysporum f. sp. phaseoli (FOP) & IV & 4 & $\mathrm{D}$ & $\mathrm{C}$ & $\mathrm{C}$ & B \\
\hline F. oxysporum f. sp. lycopersici (FOL) & I & 5 & $\mathrm{~F}$ & $\mathrm{E}$ & $\mathrm{E}$ & A \\
\hline F. oxysporum f. sp. radicis.cucumericum (FORC) & III & 6 & I & B & $\mathrm{F}$ & $\mathrm{F}$ \\
\hline F. oxysporum f. sp. radicis.lycopersici (FORL) & III & 7 & $\mathrm{~J}$ & B & $\mathrm{F}$ & G \\
\hline F. oxysporum f. sp. niveum (FON) & II & 8 & $\mathrm{~K}$ & G & G & $\mathrm{H}$ \\
\hline F. oxysporum f. sp. melonis (FOM) & III & 9 & $\mathrm{~L}$ & $\mathrm{H}$ & $\mathrm{H}$ & I \\
\hline F. oxysporum f. sp. dianthi (FOD) & II & 10 & $\mathrm{P}$ & $\mathrm{L}$ & $\mathrm{K}$ & $\mathrm{L}$ \\
\hline F. oxysporum $(F O X)$ & II & 11 & M & I & $\mathrm{E}$ & A \\
\hline F. oxysporum (FONP 1) & III & 12 & $\mathrm{G}$ & $\mathrm{F}$ & $\mathrm{E}$ & $\mathrm{D}$ \\
\hline F. oxysporum (FONP 2) & III & 13 & $\mathrm{H}$ & $\mathrm{F}$ & E & $\mathrm{D}$ \\
\hline F. oxysporum (FONP 3) & III & 14 & G & $\mathrm{F}$ & $\mathrm{E}$ & $\mathrm{E}$ \\
\hline F. proliferatum (FPRO 1) & II & 15 & $\mathrm{~N}$ & $\mathrm{~J}$ & I & $\mathrm{J}$ \\
\hline F. proliferatum (FPRO 2) & II & 16 & $\mathrm{~N}$ & $\mathrm{~J}$ & $\mathrm{~L}$ & M \\
\hline Thielaviopsis basicola (TBAS) & III & 17 & $\mathrm{E}$ & $\mathrm{D}$ & $\mathrm{D}$ & $\mathrm{C}$ \\
\hline Verticillium dahliae (VERT) & IV & 18 & $\mathrm{O}$ & $\mathrm{K}$ & $\mathrm{J}$ & $\mathrm{K}$ \\
\hline
\end{tabular}


late of $F$. oxysporum f. sp. dianthi $(F O D)$ in both PCR reactions. The additional fragments may be due to sequence variation among the thousands of copies of IGS regions within a fungal species (44) such as $F O D$, in this case. To solve this problem, we developed two different approaches. First, restriction enzyme sites were identified based on obtained nucleotide data of the sequenced portions of IGS regions that could produce different digestion fragment patterns of the PCR amplicons. PleI and Taq $\mathrm{I} a$ revealed a different digestion pattern between Australian FOV isolates and FOD isolate in both cases (Fig. 4C and D). Second, possible differentiations of melting temperature $(\mathrm{Tm})$ curves in real-time PCR products were examined using each $F O V$ specific primer pair. In both cases, the results indicated that the Tm values differed in cases of $F O V$ and $F O D$ isolates from $0.2^{\circ} \mathrm{C}$ to $0.4^{\circ} \mathrm{C}$ (for $\mathrm{FOV}-1 / \mathrm{FOV}-2$ primers) and from 0.2 to $0.6^{\circ} \mathrm{C}$ (for FOV-3/FOV-4 primers) (Fig. 4E and F).

The specificities of the two Australian $F O V$-specific primer pairs were also evaluated using two other $F O V$ races including race 3 (Egyptian) and race 4 (Indian) using real-time PCR assays. The results of amplification products in both cases clearly showed that these primer pairs were specific only for Australian FOV isolates (Fig. 5).

Real-time quantification of $\mathrm{FOV}$ DNA extracted from soil samples and cotton tissues. Different concentrations of 10-fold serially diluted $F O V$ genomic DNA ranging from $5 \times 10^{1}$ to $5 \times 10^{-3} \mathrm{ng} / \mu \mathrm{l}$ of $F O V$ 1.2 and FOV 2.1 showed single amplicons with the expected sizes of 125 and $165 \mathrm{bp}$, respectively, as determined by either melting curve analysis or agarose gel electrophoresis. The use of standard curves based on known concentrations of DNA makes it theoretically possible to quantify DNA from any source. In this study, standard curves were constructed using the abovementioned concentrations in which we plotted the samples from FOV 1.2 and FOV 2.1 infested soils or infected cotton tissues, respectively. Quantification showed linear relations $\left(R^{2}=0.994\right.$ and

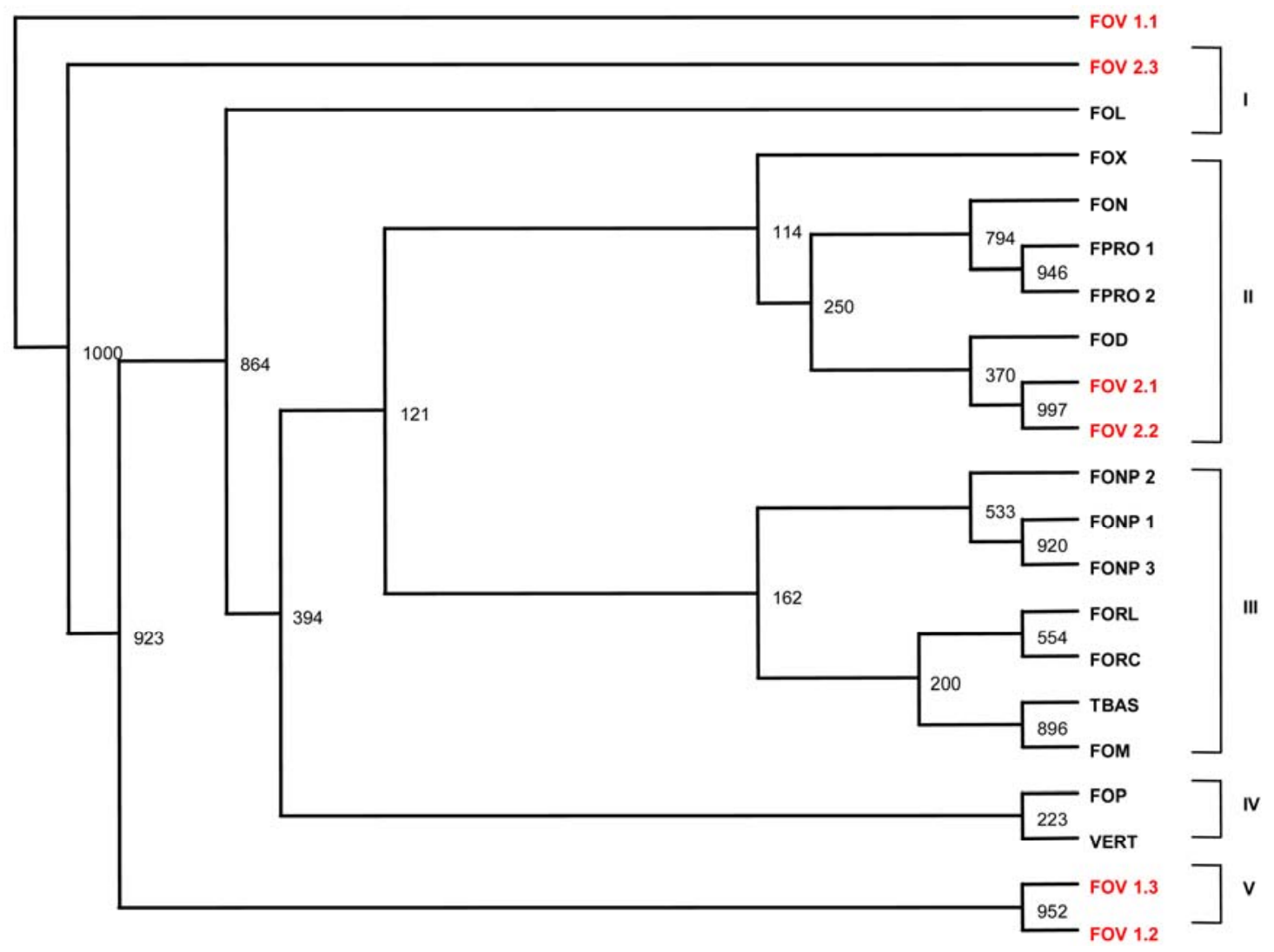

Fig. 3. Neighbor-joining tree illustrating phylogenetic relationships within the 21 fungal isolates used in the present study based on intergenic spacerrestriction fragment length polymorphism (IGS-RFLP) data. Horizontal branch lengths correspond to evolutionary distances assigned by PHYLIP program. Bootstrap values greater than $50 \%$ (based on 1,000 resamples) are indicated next to the branches.

Table 3. Quantification of Fusarium oxysporum f. sp. vasinfectum (FOV 1.2 and FOV 2.1) genomic DNA in sterile infested soil samples by real-time polymerase chain reaction

\begin{tabular}{|c|c|c|c|c|c|c|}
\hline \multirow[b]{3}{*}{ Number of conidia } & \multicolumn{6}{|c|}{ DNA amount (ng) ${ }^{w}$} \\
\hline & \multicolumn{2}{|c|}{ FOV 1.2} & \multicolumn{2}{|c|}{ FOV 2.1} & FOV 1.2 & FOV 2.1 \\
\hline & Soil type $A^{x}$ & Soil type $B^{x}$ & Soil type A & Soil type B & \multicolumn{2}{|c|}{ Mean of soils } \\
\hline $10^{4}$ & $0.01 \pm 0.001$ & $0.02 \pm 0.001$ & $\mathrm{ND}^{\mathrm{y}}$ & ND & $0.01 \pm 0.002 \mathrm{a}^{\mathrm{z}}$ & \\
\hline $10^{5}$ & $0.28 \pm 0.050$ & $0.19 \pm 0.030$ & $0.27 \pm 0.010$ & ND & $0.24 \pm 0.030 \mathrm{a}$ & $0.13 \pm 0.060 \mathrm{a}$ \\
\hline $10^{6}$ & $5.03 \pm 0.100$ & $6.93 \pm 0.170$ & $6.89 \pm 0.440$ & $7.87 \pm 1.410$ & $5.98 \pm 0.620 \mathrm{a}$ & $7.38 \pm 0.690 a$ \\
\hline $10^{7}$ & $94.29 \pm 3.330$ & $61.39 \pm 1.150$ & $64.80 \pm 7.280$ & $60.83 \pm 6.690$ & $77.84 \pm 7.520 b$ & $62.8 \pm 4.510 b$ \\
\hline Mean conidia & $24.90 \pm 12.120 \mathrm{a}^{\mathrm{z}}$ & $17.13 \pm 7.750 \mathrm{~b}$ & $17.99 \pm 8.340 \mathrm{a}$ & $17.17 \pm 7.800 \mathrm{a}$ & & \\
\hline
\end{tabular}

${ }^{w}$ Values are the mean of three replicates \pm standard error of mean.

${ }^{x}$ Composition of soil type A is $66 \%$ sand, $22 \%$ loam, $12 \%$ clay, and of soil type B is $23 \%$ sand, $47 \%$ loam, $30 \%$ clay.

y ND: not detected.

${ }^{\mathrm{z}}$ Within rows and columns, values followed by a different letter are significantly different for each FOV isolate using Sidac's studentized range test $(P<$ $0.05)$. 

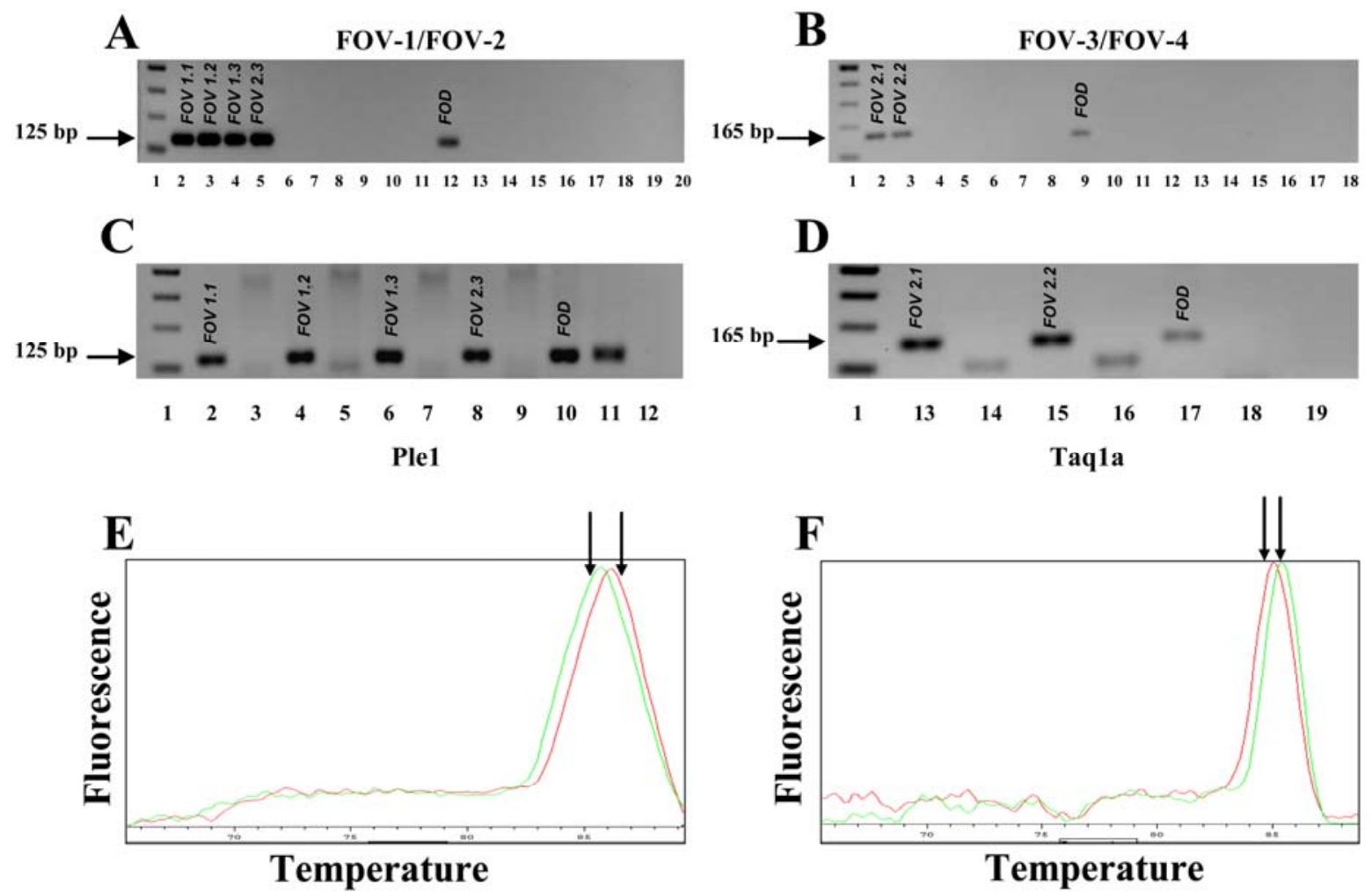

Fig. 4. A and B, Polymerase chain reactions (PCR) performed with the two primer pairs specific for Fusarium oxysporum f. sp. vasinfectum isolates (FOV1/FOV-2 and FOV-3/FOV-4, respectively). Lane 1, 100-bp DNA ladder markers; A, lanes: 2-5, amplified products of FOV isolates (FOV 1.1, FOV 1.2, FOV 1.3, FOV 2.3); 12, FOD isolate; 6-11 and 13-20, amplified products of the other tested isolates; B, lanes: 2 and 3, amplified products of $F O V$ isolates (FOV 2.1, FOV 2.2; 9, FOD isolate; 4-8 and 10-18, amplified products of the other tested isolates. C and D, Restriction digests of the previous amplicons with Ple 1 (C) and Taq1a (D): lanes: 1, 100-bp DNA ladder markers; 2,4,6,8,13,15, amplified products of FOV isolates (FOV 1.1, FOV 1.2, FOV 1.3, FOV 2.3, FOV 2.1, FOV 2.2); 10,17, amplified products of FOD isolate; 3,5,7,9,14,16, restriction products of $F O V$ amplicons (FOV 1.1, FOV 1.2, FOV 1.3, FOV 2.3, FOV 2.1, FOV 2.2); 11,18, restriction products of $F O D$ amplicons; $12,19, \mathrm{H}_{2} \mathrm{O}$. E and F, Melting curve profiles of real-time PCR-based assays using the $F O V$-specific primer pairs depicting the Tm difference in each case between FOV and FOD isolates.

A

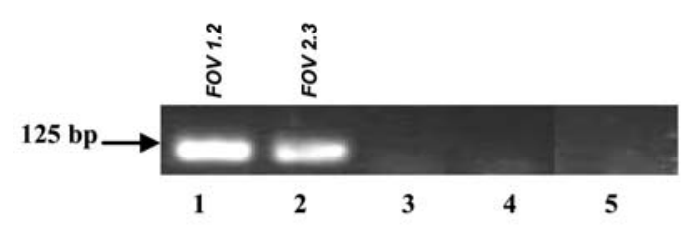

C

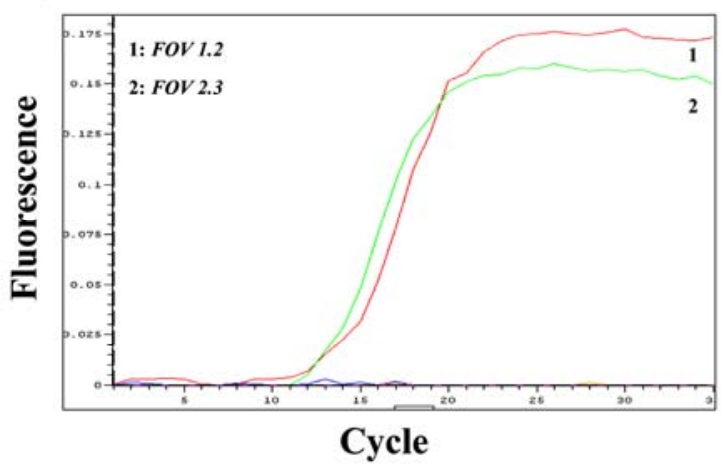

B
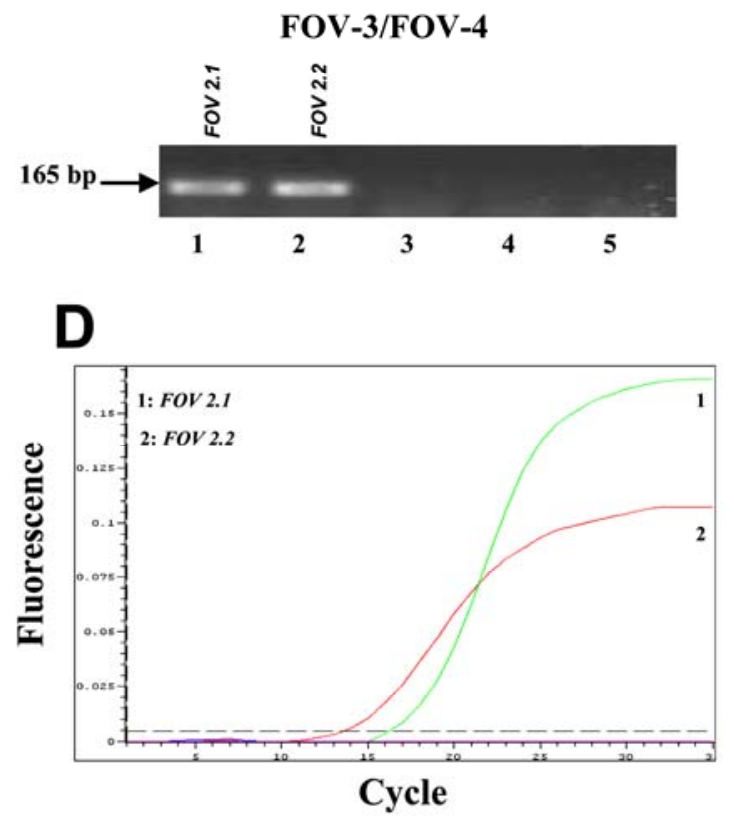

Fig. 5. A and B, Amplified products of real-time polymerase chain reactions (PCR) performed with the two primer pairs specific for Fusarium oxysporum f. sp. vasinfectum isolates (FOV-1/FOV-2 and FOV-3/FOV-4, respectively). A, Lanes: 1-2, two representative FOV isolates (FOV 1.2, FOV 2.3); 3-4, FOV (race 3 and 4) isolates; $5, \mathrm{H}_{2} \mathrm{O}$; B, lanes 1-2, two representative $F O V$ isolates $\left(F O V\right.$ 2.1, FOV 2.2); 3-4, FOV (race 3 and 4) isolates; 5, $\mathrm{H}_{2} \mathrm{O}$. C and D, Corresponding amplification plots (kinetics of fluorescence signal) of FOV 1.2 (curve 1) and FOV 2.3 (curve 2), (C) FOV 2.1 (curve 1) and FOV 2.2 (curve 2), (D) fungal DNA after using the two specific primer pairs FOV-1/FOV-2 (C) and FOV-3/FOV-4 (D). No fluorescence signal for FOV isolates race 3 and 4 was present in any real-time PCR reaction, indicative of the accuracy of the specific detection assays. 
0.993 , respectively) between $\log$ values of fungal genomic DNA and real-time PCR $\mathrm{C}_{\mathrm{T}} \mathrm{S}$ over the range of DNA concentrations examined (Fig. 6). No PCR products were obtained from any negative controls (data not shown).

The amount of FOV 1.2 or FOV 2.1 genomic DNA detected in both soils significantly increased $(P<0.0001)$ by increasing the amounts of conidia to $10^{7} / \mathrm{g}$ (Table $3)$. No significant differences between the amounts of FOV 2.1 genomic DNA ex- tracted from soil substrates were found $(P$ $=0.668)$. This was not the case with FOV 1.2 , for which the amount of genomic DNA extracted from soil B was significantly reduced $(P<0.01)$ compared to DNA from soil A (Table 3). Finally, there was a significant difference $(P=0.001)$ between the detected amounts of FOV 1.2 and FOV 2.1 genomic DNA in soil A but not in soil B $(P=0.982)$.

Table 4 shows that the amounts of FOV 1.2 and FOV 2.1 genomic DNA detected in tissues of the two cotton cultivars significantly increased $(P=0.045$ and $P<0.001$, respectively) from the resistant cv. Emerald to the susceptible cv. Lacta. Analyzing separately the results obtained in roots or hypocotyls, significant differences between the amounts of the FOV 2.1 genomic DNA were found for both cultivars $(P=0.007)$. This was quite different for the FOV 1.2 isolate in comparisons between mean differences for root and hypocotyl tissues of the resistant cv. Emerald,

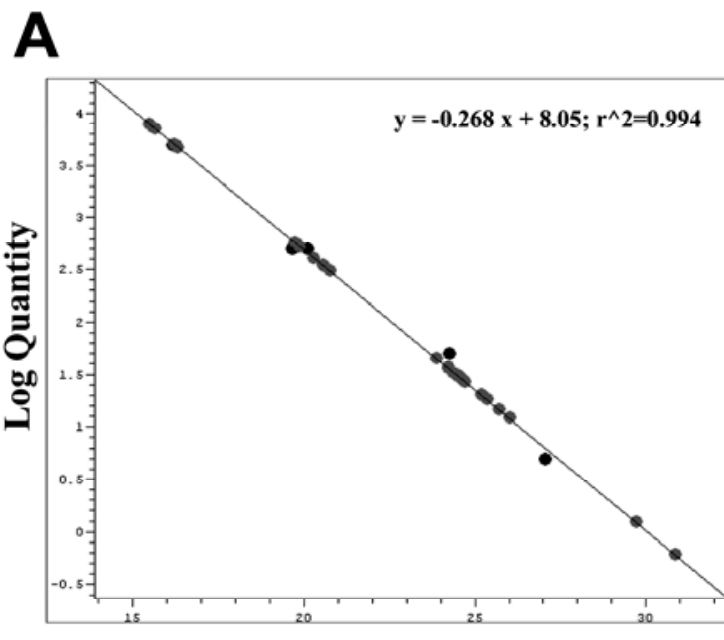

C(t) Cycle

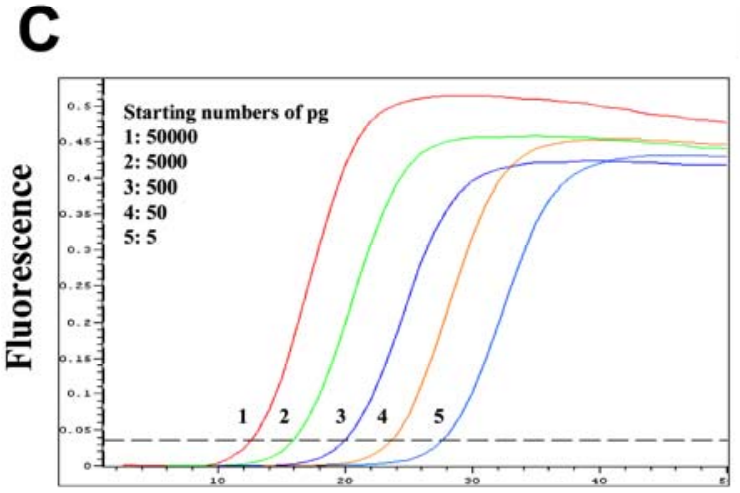

Cycle

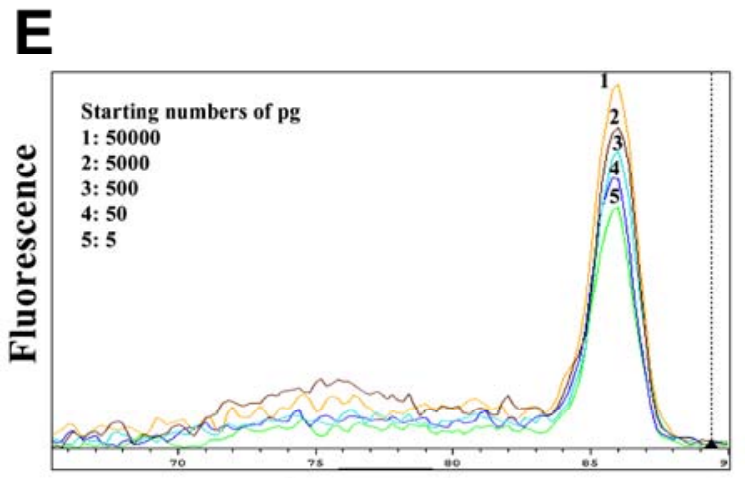

Temperature
B

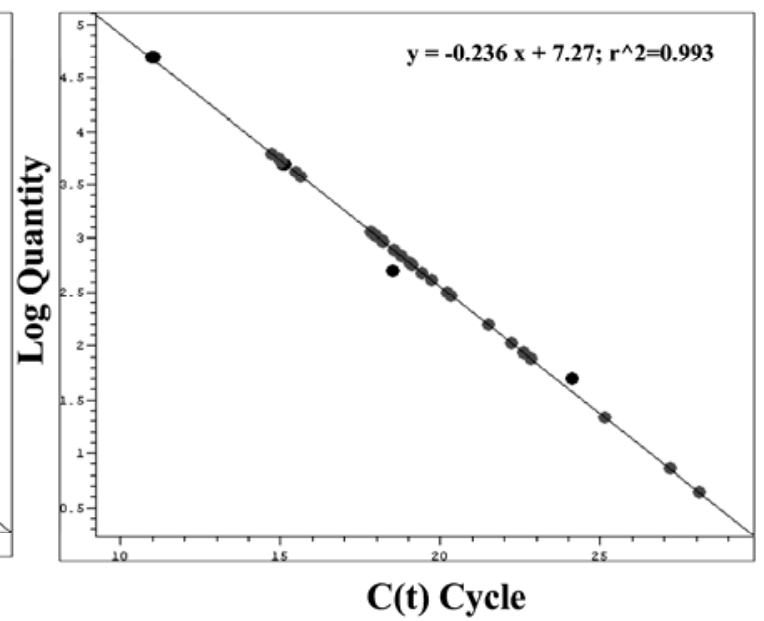

D

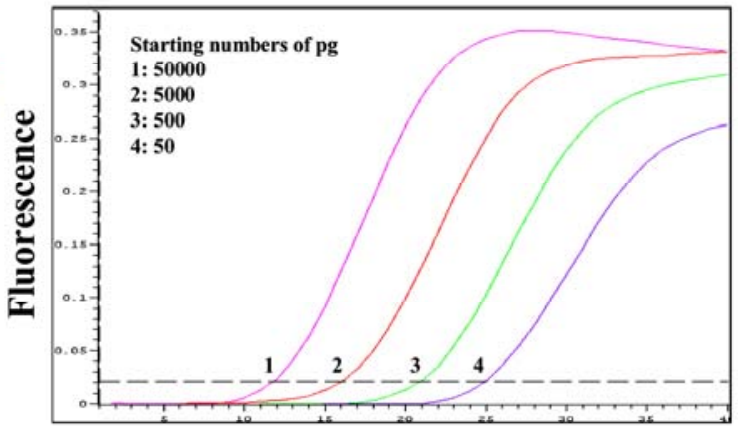

Cycle

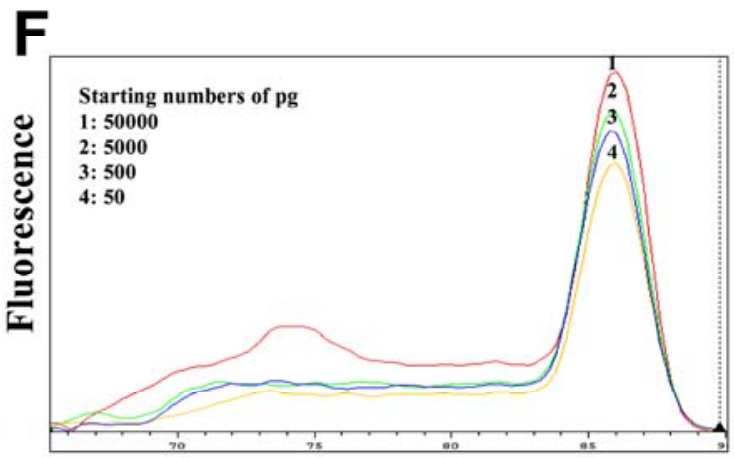

Temperature

Fig. 6. A and B, Standard curves of real-time polymerase chain reaction (PCR)-based assays used for the absolute quantification of FOV 1.2 (A) and FOV 2.1 (B) target DNA isolated from two different soil types (A and B) and from different tissues (roots and hypocotyls) of infected cotton plants (cvs. Lacta [susceptible] and Emerald [resistant]). C and D, Amplification plots (kinetics of fluorescence signal) of FOV 1.2 (C) and FOV 2.1 (D) intergenic spacer (IGS) DNA from 10-fold diluted pure genomic DNA after using the two specific primer pairs FOV-1/FOV-2 (C) and FOV-3/FOV-4 (D). E and F, Corresponding melting curve profiles where the negative derivative of fluorescence with respect to temperature is plotted as $\mathrm{dF} / \mathrm{dT}$ versus temperature to obtain a graphical representation of the melting peaks. 
where no significant differences were determined $(P=0.972)$. A significant difference in the amount of genomic DNA of FOV 2.1 extracted from hypocotyls was found between the two cultivars $(P<$ 0.001). Finally, significantly increased differences $(P=0.009$ and $P<0.001$, respectively) occurred between roots and hypocotyls when "Lacta" plants were infected with both $F O V$ isolates (Table 4).

\section{DISCUSSION}

The rapid and reliable detection of pathogens is important in developing strategies for disease management in plant nurseries (30). Our objectives were to characterize Australian FOV isolates in order to identify unique IGS-RFLP haplotypes and to develop a real-time PCRbased assay to reliably detect and quantify these isolates.

Our results indicate that IGS-RFLP analysis is a useful tool in discriminating $F O V$ isolates from all other fungal isolates used in this study. The occurrence of restriction site polymorphisms was confirmed by the identification of unique restriction profiles using the restriction enzymes AluI, RsaI, and HaeIII. The use of high-resolution metaphor gels allowed the identification of small molecular weight fragments by increasing the number of resolved polymorphic bands. Different size polymorphisms occurred even in the amplified fungal IGS products. Recently, Kim et al. (26) identified nine haplotypes based on restriction digests of the IGS region by testing 30 isolates of $F O V$ from different worldwide geographic origins. The Australian isolates comprised an independent lineage, indicating the existence of a polyphyletic evolutionary process. This is consistent with findings of Skovgaard et al. (39), who found four lineages within eight races of the pathogen. Size polymorphism in the IGS regions of $F$. oxysporum formae speciales has also been observed by Kim et al. (25). Our findings also indicate a strong diversity occurring within these similar isolates.

We were able to identify six unique restriction patterns for Australian FOV isolates (3 AluI-IGS, 2 HaeIII-IGS, and 1 RsaI-IGS) that enabled us to develop specific RFLP markers for these isolates. This IGS-RFLP approach has also been re- ported in several other studies to assess the genetic diversity of isolates within Fusarium oxysporum formae speciales such as phaseoli (1), melonis (4), and lilii (8). In these studies, isolates belonging to the same VCG exhibited the same IGS haplotype, which agrees with the hypothesis that VCGs represent clonal lineages that rarely, if ever, reproduce sexually. A similar conclusion has been reported in a study that assessed the genetic relationships among 52 isolates of $F O V$ of worldwide origin, with the exception of Australian strains, based on rDNA RFLP analysis (21).

Sequence polymorphism in the IGS region is suitable for the development of PCR-based diagnostic protocols of higher sensitivity and specificity $(9,10,34,35)$. The specificity of such a protocol for the detection and absolute quantification of Australian $F O V$ isolates was confirmed by testing them against other $F O V$ isolates from Egyptian race 3 and from Indian race 4 or against other cotton pathogenic fungi and related formae speciales that originated from Greece. These assays were also of high sensitivity, allowing the absolute quantification by real-time PCR of the two representative Australian FOV isolates FOV 1.2 and FOV 2.1. These isolates were selected for additional real-time based PCR quantitative analysis because after nucleotide alignment of the sequenced portions of the IGS regions, isolates FOV 1.2 and FOV 2.1 revealed unique and representative SNP patterns common to the four other FOV isolates (FOV 1.1, FOV 1.3, FOV 2.2, FOV 2.3), capable of distinguishing them from all the other fungal isolates used. We were able to detect amplification products by real-time PCR at the lower range of 5 and $50 \mathrm{pg} / \mu \mathrm{l}$ of target DNA, respectively. Both pairs of the Australian $F O V$-specific primers under optimized PCR conditions amplified single amplicons of 125 and $165 \mathrm{bp}$, respectively, without amplifying nontarget genomic DNA extracted from nonsterile soil substrates. Two standard curves with $R^{2}$ values from 0.994 to 0.993 were constructed, confirming the linearity of the quantification process between exponential increases of DNA concentrations and real-time PCR threshold cycles. Because $C_{T}$ values may vary slightly between experiments, we included parallel runs of three separate dilution series of pure standard DNA in all experiments.

Field soils harbor microbial complexes, making it tedious and time-consuming to isolate soilborne pathogens such as FOV by traditional agar plating. High-quality purified DNA of $F O V$ isolates extracted from infested soil substrates was obtained using the commercially available UltraClean Soil DNA Kit (MoBio Laboratories, Inc). The real-time PCR assays were highly sensitive, which allowed for detection of low levels of fungal propagules (less than $10^{4}$ conidia/g infested soil substrate, in case of FOV 1.2).

Regardless of the treatment, the 10-fold increase in conidia concentration was not linearly proportional to increases in amplified genomic DNA from both $\mathrm{FOV}$ isolates in the two soil types, particularly with samples of $10^{5}$ and $10^{6}$ conidia. Recently, Cullen et al. (13) and Fillion et al. (22), using PCR primers targeting the ribosomal region, also showed that the amount of Helminthosporium solani and Glomus intraradices DNA extracted from different soil types increased with spore concentration, but not linearly. Since fungi are known to exist in multinucleate forms (11), this nonlinear increase may be attributed to the fact that there might be multiple and different copies of ribosomal sequences present in a given fungal cell. This welldemonstrated phenomenon of ribosomal sequence polymorphism (44) could interfere with primer binding and reduce the overall efficiency of PCR that in turn would also be proportionally reduced as the amount of total target genomic DNA increases. Furthermore, we could assume that even soil composition and structure could affect the amounts of genomic DNA detected. This may be the case for FOV 1.2 DNA amount detected in soil A, which had a lighter structure and probably less coextracted humic acids and PCR inhibitors. In this case, a 20-fold decrease in DNA amount was observed after the inoculation of $10^{7}$ to $10^{6}$ conidia/g. This might also have occurred because of the lower standard curve efficiency found in independent experiments conducted. Nevertheless, the real-time PCR approach described in this study was statistically appropriate to quantify FOV genomic DNA and discriminate between different conidia quantities incor-

Table 4. Quantification of Fusarium oxysporum f. sp. vasinfectum (FOV 1.2 and FOV 2.1) genomic DNA in infected cotton tissues by real-time polymerase chain reaction

\begin{tabular}{|c|c|c|c|c|c|c|}
\hline \multirow[b]{3}{*}{ Cultivars tested } & \multicolumn{6}{|c|}{ DNA amount (ng) / 100 ng total plant genomic DNA } \\
\hline & \multicolumn{2}{|c|}{ FOV 1.2} & \multicolumn{2}{|c|}{ FOV 2.1} & \multirow{2}{*}{$\begin{array}{c}\text { FOV } 1.2 \\
\text { Mean of root and }\end{array}$} & \multirow{2}{*}{$\frac{F O V 2.1}{\text { ypocotyl tissues }}$} \\
\hline & Root & Hypocotyl & Root & Hypocotyl & & \\
\hline Emerald & $0.03 \pm 0.003$ & $0.03 \pm 0.002$ & $0.13 \pm 0.014$ & $0.08 \pm 0.003$ & $0.03 \pm 0.002 \mathrm{a}^{\mathrm{z}}$ & $0.11 \pm 0.013 \mathrm{a}$ \\
\hline Lacta & $0.04 \pm 0.006$ & $0.37 \pm 0.021$ & $0.52 \pm 0.214$ & $1.05 \pm 0.053$ & $0.20 \pm 0.074 \mathrm{~b}$ & $0.79 \pm 0.155 \mathrm{~b}$ \\
\hline Mean of cultivars & $0.03 \pm 0.003 \mathrm{a}^{\mathrm{z}}$ & $0.20 \pm 0.076 \mathrm{a}$ & $0.33 \pm 0.129 a$ & $0.57 \pm 0.219 b$ & & \\
\hline
\end{tabular}

$y$ Values are the mean of three replicates \pm standard error of mean.

${ }^{z}$ Within rows and columns, values followed by a different letter are significantly different for each $F O V$ isolate using Sidac's studentized range test $(P<$ $0.05)$. 
porated into soil samples. With regard to absolute quantification of Australian $\mathrm{FOV}$ isolates in plant tissues, higher amount of fungal genomic DNA was detected in hypocotyl tissues than in root tissues (Table 4). Furthermore, the amount of fungal genomic DNA detected was greater for susceptible cv. Lacta hypocotyls (a mean of $1.05 \mathrm{ng}$ in the case of FOV 2.1) compared with hypocotyls from the resistant cv. Emerald (a mean of $0.08 \mathrm{ng}$ ).

In conclusion, this study has shown that IGS-RFLP analysis has generated unique restriction profiles for each $F O V$ isolate, allowing the development of RFLP markers for the characterization of $F O V$ isolates and distinguishing them from all other common fungal isolates occurring in cotton fields of Greece. By combining a commercial soil DNA extraction protocol and real-time PCR-based assay using the SYBR Green dye approach described in this study, the entire fungal DNA quantification process from soil substrates to PCR results could be adequately performed in less than $2 \mathrm{~h}$.

\section{ACKNOWLEDGMENTS}

This research was funded by the General Secretariat for Research and Technology (GSRT, program PENED 10087), Greece. We thank R. Koumbroglou and D. Arhen for help in phylogenetic analysis; S. ANDRIOTIS S.A. for providing 'Emerald' seeds; W. O'Neill (Department of Primary Industries, Indooroopilly, Queensland, Australia) for providing Australian FOV isolates; C. Steinberg (INRA, Dijon, France) for providing FOV isolates belonging to race 3 (Egyptian) and race 4 (Indian); K. Elena (Benaki Phytopathological Institute of NAGREF, Athens, Greece) for access to their culture collections; and P. A. L. Dadurian and the two anonymous reviewers for their help in improving the manuscript.

\section{LITERATURE CITED}

1. Alves-Santos, F. M., Benito, E. P., Elsava, A. P., and Diaz-Minguez, J. M. 1999. Genetic diversity of Fusarium oxysporum strains from common bean fields in Spain. Appl. Environ. Microbiol. 65:3335-3340.

2. Apostolides, C. A. 1952. Contribution to the mycological flora of Greece. Ann. Inst. Phytopathol. Benaki 6:62-78.

3. Appel, D. J., and Gordon, T. R. 1995. Intraspecific variation within populations of Fusarium oxysporum based on RFLP analysis of the intergenic spacer region of the rDNA. Exp. Mycol. 19:120-128.

4. Appel, D. J., and Gordon, T. R. 1996. Relationships among pathogenic and nonpathogenic isolates of Fusarium oxysporum based on the partial sequence of the intergenic spacer region of the ribosomal DNA. Mol. PlantMicrobe Interact. 9:125-138.

5. Armstrong, G. M., and Armstrong, J. K. 1981. Formae speciales and races of Fusarium oxysporum causing wilt diseases. Pages 391-399 in: Fusarium: Diseases, Biology, and Taxonomy. P. E. Nelson, T. A. Toussoun, and R. J. Cook, eds. Pennsylvania State University, University Park.

6. Atkins, S. D., and Clark, I. M. 2004. Fungal molecular diagnostics: A mini review. J. Appl. Genet. 5:3-15.

7. Atkins, S. D., Clark, I. M., Sosnowska, D., Hirsch, P. R., and Kerry, B. R. 2003. Detection and quantification of Plectosphaerella cucumerina, a potential biological control agent of potato cyst nematodes, by using conventional PCR, real-time PCR, selective media, and baiting. Appl. Environ. Microbiol. 69(8):47884793.

8. Baayen, R. P., Forch, M. G., Waalwijk, C., Bonants, P. J. M., Loffler, H. J. M., and Roebroeck, E. J. A. 1998. Pathogenic, genetic and molecular characterisation of Fusarium oxysporum f. sp. lilii. Eur. J. Plant Pathol. 104:887-894.

9. Bates, J. A., Taylor, E. J. A., Kenyon, D. M., and Thomas, J. E. 2001. The application of real-time PCR to the identification, detection and quantification of Pyrenophora species in barley seed. Mol. Plant Pathol. 2:49-57.

10. Botha, W. J., Serfontein, S., Greyling, M. M., and Berger, D. K. 2001. Detection of Xylophilus ampelinus in grapevine cuttings using a nested polymerase chain reaction. Plant Pathol. 50:515-525.

11. Bridge, P., and Spooner, B. 2001. Soil fungi: Diversity and detection. Plant Soil 232:147154.

12. Carter, J. P., Rezanoor, H. N., Desjardins, A. E., and Nicholson, P. 2000. Variation in Fusarium graminearum isolates from Nepal associated with their host of origin. Plant Pathol. 49:452-460.

13. Cullen, D. W., Lees, A. K., Toth, I. K., and Duncan, J. M. 2001. Conventional PCR and real-time PCR detection of Helminthosporium solani in soil and on potato tubers. Eur. J. Plant Pathol. 107:387-398.

14. Cullen, D. W., Lees, A. K., Toth, I. K., and Duncan, J. M. 2002. Detection of Colletotrichum coccodes from soil and potato tubers by conventional and quantitative real-time PCR. Plant Pathol. 51:281-292.

15. Davis, R. M., Colyer, P. D., Rothrock, C. S., and Kochman, J. K. 2006. Fusarium wilt of cotton: Population diversity and implications for management. Plant Dis. 90:692-703.

16. Davis, R. M., Moore, N. Y., and Kochman, J. K. 1996. Characterization of a population of Fusarium oxysporum f. sp. vasinfectum causing wilt of cotton in Australia. Aust. J. Agric. Res. 47:1143-1156.

17. Dhingra, O. D., and Sinclair, J. B. 1985. Basic Plant Pathology Methods. CRC Press, Boca Raton, FL.

18. do Schena, L., Nigro, F., Ippolito, A., and Gallitelli, D. 2004. Real-time quantitative PCR: A new technology to detect and study phytopathogenic and antagonistic fungi. Eur. J. Plant Pathol. 110:893-908.

19. Felsenstein, J. 2002. Quantitative characters, phylogenies and morphometrics. Pages 27-44 in: Morphology, Shape, and Phylogenetics. N. MacLeod, ed. Systematics Association Special Volume Series 64. Taylor and Francis, London.

20. Felsenstein, J. 2002. Contrasts for a withinspecies comparative method. Pages 118-129 in: Modern Developments in Theoretical Population Genetics. M. Slatkin and M. Veuille, eds. Oxford University Press, Oxford.

21. Fernandez, D., Assigbetes, K. B., Dubois, M. P., and Geiger, J. P. 1994. Molecular characterization of races and vegetative compatibility groups in Fusarium oxysporum f. sp. vasinfectum. Appl. Environ. Microbiol. 60:4039-4046.

22. Fillion, M., St-Arnaud, M., and Jabaji-Hare, S H. 2003. Direct quantification of fungal DNA from soil substrate using real-time PCR. J. Microbiol. Methods 53:67-76.

23. Hillis, D. M., and Dixon, M. T. 1991. Ribosomal DNA: Molecular evolution and phylogenetic inference. Q. Rev. Biol. 66:411-453.

24. Keppel, G., and Wickens, T. D. 2004. Design and Analysis: A Researcher's Handbook, 4th ed. Pearson, Upper Saddle River, NJ.

25. Kim, H.-J., Choi, Y.-K., and Min, B.-R. 2001. Variation of the Intergenic Spacer (IGS) region of ribosomal DNA among Fusarium ox- ysporum formae speciales. J. Microbiol. 39:265-272

26. Kim, Y., Hutmacher, R. B., and Davis, R. M 2005. Characterization of California isolates of Fusarium oxysporum f. sp. vasinfectum. Plant Dis. 89:366-372.

27. Konstantinova, P., and Yli-Mattila, T. 2004 IGS-RFLP analysis and development of molecular markers for identification of Fusarium poae, Fusarium langsethiae, Fusarium sporotrichioides and Fusarium kyushuense. Int. J. Food Microbiol. 95:321-331.

28. Lees, A. K., Cullen, D. W., Sullivan, L., and Nicolson, M. J. 2002. Development of conventional and quantitative real-time PCR assays for the detection and identification of Rhizoctonia solani $A G-3$ in potato and soil. Plant Pathol. 51:293-302.

29. Li, S., and Hartman, G. L. 2003. Molecular detection of Fusarium solani f. sp. glycines in soybean roots and soil. Plant Pathol. 52:74-83.

30. McCartney, H. A., Foster, S. J., Fraaije, B. A. and Ward, E. 2003. Molecular diagnostics for fungal plant pathogens. Pest Manag. Sci. 59(2): 129-142.

31. Morrison, T. B., Ma, Y., Weis, J. H., and Weis, J. J. 1999. Rapid and sensitive quantification of Borrelia burgdorferi-infected mouse tissues by continuous fluorescent monitoring of PCR. J. Clin. Microbiol. 37:987-992.

32. Nitsche, A., Steuer, N., Schmidt, C. A., Landt, O., and Siegert, W. 1999. Different real-time PCR formats compared for the quantitative detection of human cytomegalovirus DNA. Clin. Chem. 45:1932-1937.

33. Page, R. D. M. 1996. TREEVIEW: An application to display phylogenetic trees on personal computers. Computer Applications Biosci. 12: $357-358$.

34. Pastrik, K. H., Elphinstone, J. G., and Pukall, R. 2002. Sequence analysis and detection of Ralstonia solanacearum by multiplex PCR amplification of $16 \mathrm{~S}-23 \mathrm{~S}$ ribosomal intergenic spacer region with internal positive control. Eur. J. Plant Pathol. 108:831-842.

35. Patino, B., Mirete, S., Gonzalez-Jaen, M. T., Mule, G., Rodriguez, M. T., and Vazquez, C. 2004. PCR detection assay of fumonisinproducing Fusarium verticillioides strains. J. Food Prot. 67:1278-1283.

36. Reischer, G. H., Lemmens, M., Farnleitner, A., Adler, A., and Mach, R. L. 2004. Quantification of Fusarium graminearum in infected wheat by species specific real-time PCR applying a TaqMan Probe. J. Microbiol. Methods 59(1):141-146

37. Schnerr, H., Niessen, L., and Vogel, R. F. 2001 Real-time detection of the tri5 gene in Fusa rium species by LightCyclerk-PCR using SYBR Green I for continuous fluorescence monitoring. Int. J. Food Microbiol. 71:53-61

38. Schweigkofler, W., O'Donnell, K., and Garbelotto, M. 2004. Detection and quantification of airborne conidia of Fusarium circinatum, the causal agent of pine pitch canker, from two California sites by using a real-time PCR approach combined with a simple spore trapping method. Appl. Environ. Microbiol. 70(6):35123520

39. Skovgaard, K., Nirenberg, H. I., O'Donnell, K., and Rosendahl, S. 2001. Evolution of Fusarium oxysporum f. sp. vasinfectum races inferred from multigene genealogies. Phytopathology 91:1231-1237.

40. Snyder, W. C., and Hansen, H. N. 1940. The species concept in Fusarium. Ann. J. Bot. 27:64-67.

41. Tomlinson, J. A., Boonham, N., Hughes, K. J., Griffin, R. L., and Barker, I. 2005. Onsite DNA extraction and real-time PCR for detection of Phytophthora ramorum in the field. Appl. Environ. Microbiol. 71(11):6702 6710

42. Ward, L. I., Beales, P. A., Barnes, A. V., an 
Lane, C. R. 2004. A real-time PCR assay based method for routine diagnosis of Spongospora subterranean on potato tubers. J. Phytopathol. 152:633-638.

43. Weller, S. A., Elphinstone, J. G., Smith, N. C., Boonham, N., and Stead, D. E. 2000. Detection of Ralstonia solanacearum strains with a quantitative, multiplex, real-time, fluorogenic PCR (Taq-Man) assay. Appl. Environ. Micro- biol. 66:2853-2858.

44. White, T. J., Bruns, T., Lee, S., and Taylor, J. 1990. Amplification and direct sequencing of fungal ribosomal RNA genes for phylogenetics. Pages 315-322 in: PCR Protocols: A Guide to Methods and Applications. M. A. Innis, D.

H. Gelfand, J. J. Sninsky, and T. J. White, eds. Academic Press, San Diego.

45. Winton, L. M., Stone, J. K., Watrud, L. S., and
Hansen, E. M. 2002. Simultaneous one-tube quantification of host and pathogen DNA with real-time polymerase chain reaction. Phytopathology 92:112-116.

46. Zhang, Z., Zhang, J., Wang, Y., and Zheng, X. 2005. Molecular detection of Fusarium ox ysporum f. sp. niveum and Mycosphaerella melonis in infected plant tissues and soil FEMS Microbiol. Lett. 249(1):39-47. 